\title{
Case Report: Prolonged Viral Shedding in Six COVID-19 Patients
}

\author{
Arwa E. Alsaud, ${ }^{1}$ Arun Prabhakaran Nair, ${ }^{2}$ Ahmad S. Matarneh, ${ }^{1 \star}$ Sreethish Sasi, ${ }^{1}$ Rania El Hassan, ${ }^{1}$ Fahmi Khan, ${ }^{1}$ Peter Coyle, ${ }^{3}$ \\ Mohamed Abu Khattab, ${ }^{2}$ and Mouhand F. H. Mohamed ${ }^{1}$ \\ ${ }^{1}$ Department of Medicine, Hamad General Hospital, Hamad Medical Corporation, Doha, Qatar; ${ }^{2}$ Department of Infectious Diseases, \\ Communicable Disease Center, Hamad Medical Corporation, Doha, Qatar; ${ }^{3}$ Department of Virology, Hamad General Hospital, \\ Hamad Medical Corporation, Doha, Qatar
}

\begin{abstract}
COVID-19 has surfaced as a multi-organ disease predominantly affecting the respiratory system. Detection of the viral RNA through reverse transcriptase-PCR (RT-PCR) from a nasopharyngeal or throat sample is the preferred method of diagnosis. Recent evidence has suggested that COVID-19 patients can shed the SARS-CoV-2 for several weeks. Herein, we report six cases of COVID-19 who had persistently positive SARS-CoV-2 on repeat RT-PCR testing reaching up to 9 weeks. The spectrum of cases described ranges from asymptomatic infection to severe COVID-19 pneumonia. A full understanding of the virus's transmission dynamics needs further research. Prolonged viral shedding currently has unclear implications on the management and isolation decisions-the role of the cycle threshold (Ct) value in guiding therapeutic decisions is yet to be clarified. More data on the relationship between Ct values and viral cultivation are needed, especially in patients with prolonged viral shedding, to understand the virus's viability and infectivity.
\end{abstract}

\section{INTRODUCTION}

Although SARS-CoV-2 infection most often presents as asymptomatic or as mild upper respiratory tract infection (URTI), almost $14 \%$ of patients develop severe disease requiring hospitalization, including $5 \%$ needing intensive care unit (ICU) admission. ${ }^{1}$ COVID-19 can result in serious injuries, including acute respiratory distress syndrome, sepsis, acute kidney, heart failure, and multi-organ failure. Older age and increasing comorbidities are risks for higher mortality. ${ }^{1,2}$ Currently, many diagnostic tests are available for COVID-19 with variable sensitivities. ${ }^{3}$ Nonetheless, viral RNA detection by reverse transcription-PCR remains the preferred method to establish the diagnosis. Serological detection of IgM and IgG antibodies against the virus using ELISA is also used for screening purposes and to identify past infection or immunity. However, its diagnostic value and accuracy are being evaluated. $^{3}$

Recent studies showed that patients could asymptomatically shed SARS-CoV-2 for weeks. ${ }^{4,5}$ Herein, we report six cases of COVID-19 who showed persistent positive SARSCoV-2 on repeated RT-PCR nasopharyngeal swab testing for varying durations, reaching 9 weeks after the initial diagnosis.

\section{CASE PRESENTATION}

Case 1. The first case is a 74-year-old man known to have asthma, diabetes mellitus (DM), hypertension (HTN), coronary artery disease (CAD), and dyslipidemia (Table 1). He was admitted to a quarantine facility because of an asymptomatic COVID-19 infection identified through screening (RT-PCR). The local guideline at the time warranted two negative PCR swabs before discharge. SARS-CoV-2 was repeatedly positive for 49 days. He showed clinical improvement and was discharged after negative results (Table 1).

Case 2. A healthy 19-year-old man presented with a short history of fever and sore throat. The examination was remarkable for low-grade fever and tachycardia, and laboratory

*Address correspondence to Ahmad S. Matarneh, Internal Medicine Department, Hamad Medical Corporation, Al Nasser Street, P.O. Box 3050, Doha, Qatar. E-mail: amatarneh@hamad.qa investigations and chest X-ray were unremarkable. He was diagnosed as a case of COVID-19 mild URTI and did not require hospital admission but transited through quarantine. His PCR swab remained positive for 48 days.

Case 3. A previously healthy 46-year-old man presented with a 7-day history of fever, dry cough, and mild dyspnea. On examination, he was febrile, mildly tachypneic, tachycardic, but maintained oxygen saturation on room air. His chest $X$-ray revealed consolidation involving the left mid and lower zones. SARS-CoV-2 PCR tested positive, and he was started on COVID-19 management for pneumonia following local protocols. The repeated PCR tests were persistently positive for 47 days. The patient was discharged home, asymptomatic after negative PCR.

Case 4. A 53-year-old man, known to have HTN, DM, and end-stage renal disease (ESRD), presented with fever, abdominal pain, diarrhea, nausea, and vomiting. Physical examination revealed a tired-looking man with mild abdominal tenderness but was otherwise unremarkable. Abdominal computed tomography (CT) scan was performed to rule out causes of acute abdomen. It showed no abdominal pathology but numerous bilateral lungs' basal patchy consolidations and ground-glass opacities. Subsequently, nasopharyngeal PCR confirmed COVID-19. He received the treatment guided by the local protocol, and he became symptom-free and was discharged home following negative swab PCR after 28 days. Eighteen days later, he again presented with fever, chest pain, and mild dyspnea. The chest X-ray showed bilateral lung infiltrates increasing compared with the previous Images. The initial test for COVID-19 was inconclusive; then, the repeat test was positive 2 days after the second hospital admission. He was restarted on the treatment protocol and continued to improve with an unremarkable hospital stay. The repeated test was negative after 1 week from the second presentation. The patient had 48 days elapsing from the first positive PCR result until the last positive sample.

Case 5. A 35-year-old man presented with a 10-day history of fever, headache, and dry cough. Physical examination was unremarkable. His baseline blood investigation was remarkable for high inflammatory markers and mild transaminitis. Chest X-ray revealed left mid-zone consolidation with a cavitary lesion. He was found to be positive for SARS-CoV-2 from 
TABLE 1

Summary of baseline characteristics, clinical features, and laboratory test results, diagnoses, treatments, and outcomes of six cases with prolonged viral shedding

\begin{tabular}{|c|c|c|c|c|c|c|}
\hline Characteristic & Patient 1 & Patient 2 & Patient 3 & Patient 4 & Patient 5 & Patient 6 \\
\hline \multicolumn{7}{|l|}{ Demographics } \\
\hline Age (years) & 74 & 19 & 46 & 53 & 35 & 65 \\
\hline Gender (M: male) & M & M & $\mathrm{M}$ & M & M & M \\
\hline Comorbid conditions & $\begin{array}{l}\text { DM2, HTN, } \\
\text { Coronary } \\
\text { artery disease, } \\
\text { and BA }\end{array}$ & None & None & $\begin{array}{l}\mathrm{DM} 2, \mathrm{HTN} \text {, and } \\
\text { end-stage } \\
\text { renal disease }\end{array}$ & $\begin{array}{l}\text { Pulmonary } \\
\text { tuberculosis }\end{array}$ & $\begin{array}{l}\text { Chronic myeloid } \\
\text { leukemia on active } \\
\text { immunosuppressive } \\
\text { therapy }\end{array}$ \\
\hline \multicolumn{7}{|c|}{ Presenting symptoms, and clinical and radiological features on admission } \\
\hline Symptoms & NA & $\begin{array}{l}\text { Fever and } \\
\text { sore throat }\end{array}$ & $\begin{array}{l}\text { Fever, cough, } \\
\text { and SOB }\end{array}$ & $\begin{array}{l}\text { Fever, diarrhea } \\
\text { and abdominal } \\
\text { pain }\end{array}$ & $\begin{array}{l}\text { Fever, headache, } \\
\text { and cough }\end{array}$ & $\begin{array}{l}\text { Fever, cough, and } \\
\text { SOB }\end{array}$ \\
\hline $\begin{array}{l}\text { Symptoms' duration } \\
\text { before admission (days) }\end{array}$ & NA & $2-3$ & 7 & $4-5$ & 10 & $5-6$ \\
\hline $\begin{array}{l}\text { Oxygen saturation (\%) on } \\
\text { room air }\end{array}$ & 99 & 99 & 100 & 96 & 99 & 97 \\
\hline Chest X-ray & Normal & Normal & $\begin{array}{l}\text { Bilateral } \\
\text { consolidations }\end{array}$ & $\begin{array}{l}\text { Bilateral patchy } \\
\text { infiltrates }\end{array}$ & $\begin{array}{l}\text { Left lung opacity/ } \\
\text { cavitary lesion }\end{array}$ & $\begin{array}{l}\text { Bilateral lower lobes } \\
\text { collapse with } \\
\text { effusion }\end{array}$ \\
\hline \multicolumn{7}{|l|}{ Laboratory tests on admission } \\
\hline $\begin{array}{l}\text { White blood cell count } \\
\quad(4-10 \times 103 / \mu \mathrm{L})\end{array}$ & NA & 9.7 & 7.4 & 6.3 & 8.6 & 3.8 \\
\hline $\begin{array}{l}\text { Hemoglobin (13-17 } \\
\text { gm/dL) }\end{array}$ & NA & 17.4 & 11.7 & 14.8 & 11.3 & 7.5 \\
\hline 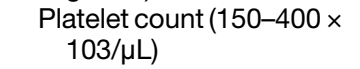 & NA & 260 & 181 & 152 & 511 & 42 \\
\hline $\begin{array}{l}\text { Absolute neutrophil } \\
\text { count }(2-7 \times 103 / \mu \mathrm{L})\end{array}$ & NA & 7.32 & 4.9 & 4.5 & 7 & 0.4 \\
\hline $\begin{array}{l}\text { Lymphocyte count }(1-3 \times \\
103 / \mu L)\end{array}$ & NA & 1.68 & 2.2 & 1.22 & 1 & 0.9 \\
\hline $\begin{array}{l}\text { C-reactive protein } \\
(0-5 \mathrm{mg} / \mathrm{L})\end{array}$ & NA & NA & 49.9 & 30 & 225 & 74.6 \\
\hline $\begin{array}{l}\text { Lactate dehydrogenase } \\
\quad(135-225 \mathrm{U} / \mathrm{L})\end{array}$ & NA & NA & 282 & NA & NA & 201 \\
\hline Ferritin $(30-490 \mu \mathrm{g} / \mathrm{L})$ & NA & NA & 664 & NA & 3,439 & 286 \\
\hline D-dimer $(<0.4 \mathrm{mcg} / \mathrm{mL})$ & NA & NA & NA & NA & NA & 3.41 \\
\hline $\begin{array}{l}\text { Creatinine (63.6-110.5 } \\
\qquad \mu \mathrm{mol} / \mathrm{L})\end{array}$ & NA & 81 & 86 & 1,112 & 61 & 80 \\
\hline $\begin{array}{l}\text { Alanine aminotransferase } \\
\quad(0-55 \mathrm{U} / \mathrm{L})\end{array}$ & NA & 26.4 & 32 & 12.6 & 42 & 10 \\
\hline $\begin{array}{l}\text { Aspartate } \\
\text { aminotransferase } \\
\text { (5-34 U/L) }\end{array}$ & NA & 22 & 35 & 24 & 92 & 17 \\
\hline \multicolumn{7}{|l|}{ Diagnosis } \\
\hline & Asymptomatic & $\begin{array}{l}\text { Upper } \\
\text { respiratory } \\
\text { tract } \\
\text { infection }\end{array}$ & Pneumonia & Pneumonia & Pneumonia & Pneumonia \\
\hline \multicolumn{7}{|l|}{ Treatment } \\
\hline Hydroxychloroquine & No & No & Yes & Yes & Yes & No \\
\hline Antivirals & No & No & Yes & Yes & Yes & Yes \\
\hline Antibiotics & No & No & Yes & Yes & Yes & Yes \\
\hline Corticosteroid & No & No & No & No & No & No \\
\hline Tocilizumab & No & No & No & No & No & Yes \\
\hline \multicolumn{7}{|l|}{ Outcome } \\
\hline $\begin{array}{l}\text { Intensive care unit } \\
\text { admission }\end{array}$ & No & No & No & No & No & Yes \\
\hline Invasive ventilation & No & No & No & No & No & No \\
\hline Noninvasive ventilation & No & No & No & No & No & Yes \\
\hline Supplemental oxygen & No & No & No & Yes & No & Yes \\
\hline $\begin{array}{l}\text { Total symptoms' } \\
\text { duration (days) }\end{array}$ & NA & 4 & NA & 15 & 20 & 35 \\
\hline $\begin{array}{l}\text { Time to radiologic } \\
\text { recovery (days) }\end{array}$ & NA & NA & NA & 14 & 46 & 47 \\
\hline
\end{tabular}

nasopharyngeal swab PCR. Given the cavitary lesion, tuberculosis (TB) was suspected, and sputum smear acid-fast bacilli confirmed the presence of mycobacterial infection. Thus, the patient was treated as a case of COVID-19 pneumonia and active pulmonary TB. TB culture showed Mycobacterium tuberculosis sensitive for first-line anti-TB drugs. He later developed a rise in liver enzymes suspected to be either secondary to TB drugs versus COVID-19-related hepatitis. 
Subsequently, he was shifted temporarily to second-line antituberculosis therapy until improvement in his liver enzymes. Re-swabbing was performed as per the protocol, and the patient tested persistently positive for a total of 62 days.

Case 6. This is a 65-year-old man known to have chronic myeloid leukemia (CML) on dasatinib. He presented with a short history of fever, productive cough, and dyspnea. The examination revealed low-grade fever, tachycardia, and bilateral rhonchi on chest examination. Chest X-ray showed bilateral lower lobe consolidation with effusion. SARS-CoV-2 PCR was positive, and he was subsequently diagnosed as a severe case of COVID-19 pneumonia and received antibiotics and antiviral drugs. His condition deteriorated further during his stay, requiring noninvasive ventilation and ICU admission for 7 days. He eventually improved and was stepped down to the general medical wards for post-ICU care. He continued to have positive PCR for 54 days from the initial positive test.

\section{DISCUSSION}

Coronaviruses have structural proteins, including envelope $(\mathrm{E})$, nucleocapsid (N), and spike (S) proteins. Their replication and transcription are expressed from an open reading frame called ORF1ab, and RNA dependent on the RNA polymerase gene (RdRp). The ORF1ab, E, RdRp, N, and S genes are the targets used for the detection of SARS-CoV-2 by RT-PCR. ${ }^{6}$

SARS-CoV-2 may be detected via an upper respiratory tract PCR sample a few days before symptom onset. Viral shedding persists for varying periods after symptoms' onset, with a study reporting a median duration of 11 days. ${ }^{7}$ Newer evidence suggested the long-term shedding of SARS-CoV-2 in the urine and stool of infected patients even when their nasopharyngeal swabs were negative. ${ }^{8,9}$ Factors independently associated with prolonged respiratory viral shedding include fever $\left(>38.5^{\circ} \mathrm{C}\right)$, severe disease, old age (>60), male gender, concomitant HTN, steroid use, invasive ventilation, ICU admission, and lack of antiviral drugs. ${ }^{7,10-13}$

Although some investigators observed a longer duration of viral shedding in symptomatic patients, ${ }^{14}$ our patients ranged from having an asymptomatic infection (case 1) to severe COVID-19 pneumonia (case 6). All had prolonged viral shedding ranging between 6 and 9 weeks, as depicted by PCR (Figure 1). The periods reported in our series are an underrepresentation of the exact shedding window. The shedding likely exceeded these periods as we calculated only from the first positive test till the last positive test; this excludes shedding before diagnosis and between the last positive and first negative tests. Interestingly, cases 5 and 6 had the most extended shedding window, which may be attributed to their immunosuppressed status (active pulmonary tuberculosis and CML on active chemotherapy, respectively). Two recently reported leukemia and lymphoma cases shed the virus for 70 and 60 days, respectively. ${ }^{15,16}$ The mechanism by which immunosuppressed status affects SARS-CoV-2 shedding is not well elucidated. ${ }^{16}$ Nonetheless, derangement of T-cell immune function, which has a strong role in COVID-19 pathophysiology, is likely involved. ${ }^{17}$ Similarly, impaired immunity and the accompanying increased viral load might have delayed resolution in diabetic patients in cases 1 and $4 .^{18}$

Bullard et al. ${ }^{19}$ tried to describe the infectiousness through viral cultures and found that viable SARS-CoV-2 was cultured when the RT-PCR cycle threshold (Ct) value was $<24$ and within less than 8 days from symptoms onset. Singanayagam et al. ${ }^{20}$ also found a strong correlation between the Ct value and viral load with a probability of retrieving viable virus, declining to $8 \%$ in samples with $\mathrm{Ct}>35$, and 6\% 10 days after symptoms onset. In line with these findings, multiple Ct value cutoffs were used by different guidelines generating bodies to define the infectivity and guide isolation decisions, which has led to differences in reported COVID-19 prevalence. Nonetheless, RT-PCR positivity is a surrogate that does not necessarily indicate that an individual is infectious or is shedding live viruses. Moreover, the optimal Ct value cutoff is unknown. The CDC and the WHO do not recommend using a test-based strategy guided by the $\mathrm{Ct}$ value to ascertain infectivity, at least at this stage. ${ }^{21,22}$ At the time of this series, our local protocol initially mandated two negative PCR results, and it was revised later in the mid of our patient's observation to a single negative test. The adopted Ct value cutoff was 33 to guide isolation discontinuation decisions in hospitalized patients. Time lines of the nasopharyngeal PCR Ct value in our cases showed

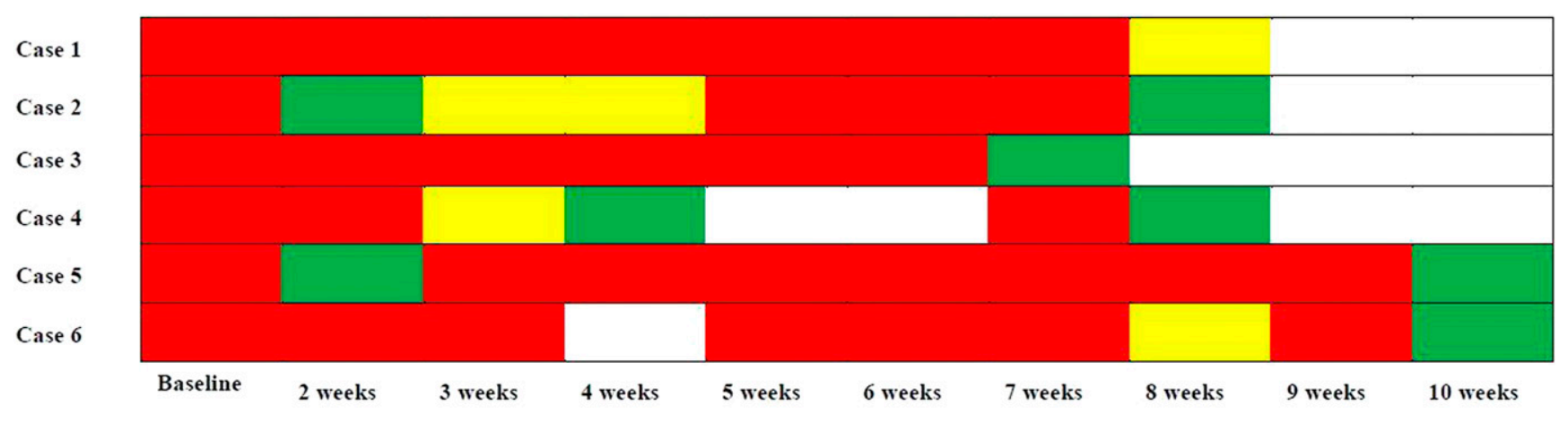

\begin{tabular}{|l|}
\hline Positive \\
\hline Inconclusive \\
\hline Negative \\
\hline Not done \\
\hline
\end{tabular}

FIGURE 1. Schematic presentation of SARS-CoV-2 PCR results. This figure appears in color at www.ajtmh.org. 
that multiple gene loci fall under the infectious range (Supplemental Table 1). Median Ct values at 2 weeks and even above 6 weeks showed a CT value of less than 33, possibly suggesting high viral load. Most patients had persistent shedding despite symptoms' resolution; this could imply a carrier state and prolonged infectivity possibly exceeding 6 weeks. To review the possibility of reinfection or relapse in case 4, we analyzed his Ct values chronologically and assessed his Ct values using different genes. When this patient was discharged at 28 days, he had two negative results with the Thermo Fisher kit showing a Ct value $>40$ on all gene locus (N, Orf, and S). After 18 days, he presented to the hospital again with clinical and radiological worsening with a $\mathrm{Ct}$ value of 32 in Roche E-gene. It is not clear whether this represents a relapse with the same virus with prolonged viral shedding or reinfection with a new virus from the community.

\section{CONCLUSION}

In this case series, we observe a persistent viral shedding in patients with immunosuppressive conditions such as DM, leukemia, tuberculosis, and severe COVID-19 pneumonia. SARS-CoV-2 prolonged shedding currently has unclear implications on the management and isolation decisions-the role of the $\mathrm{Ct}$ value in guiding infection control decisions is yet to be clarified. More data on the relationship between viral and $\mathrm{Ct}$ values are needed, especially in patients with prolonged viral shedding, to assess the virus's viability and infectivity.

Received August 1, 2020. Accepted for publication February 15, 2021. Published online February 24, 2021.

Note: Supplemental table appears at www.ajtmh.org.

Acknowledgments: We thank Hamad Medical Corporation for supporting academic research and the medical staff involved in the care of COVID-19 patients. Publication charges for this article were waived due to the ongoing pandemic of COVID-19.

Disclosure: We sought local IRB approval for the publication of this case series. All patients provided verbal consent for the publication of this case series.

Authors' addresses: Arwa E. Alsaud, Ahmad S. Matarneh, Sreethish Sasi, Rania El Hassan, Fahmi Khan, and Mouhand F. H. Mohamed, Department of Medicine, Hamad General Hospital, Hamad Medical Corporation, Doha, Qatar, E-mails: arwa.alsaud@gmail.com, amatarneh@ hamad.qa, sreethishsasi@gmail.com, raniadoc71@hotmail.com, fkhan@ hamad.qa, and dr.m.oraiby@hotmail.com. Arun Prabhakaran Nair and Mohamed Abu Khattab, Department of Infectious Diseases, Communicable Disease Center, Hamad Medical Corporation, Doha, Qatar, E-mails: anair9@hamad.qa and mabukhattab@hamad.qa. Peter Coyle, Department of Virology, Hamad General Hospital, Hamad Medical Corporation, Doha, Qatar, E-mail: pcoyle@hamad.qa.

This is an open-access article distributed under the terms of the Creative Commons Attribution (CC-BY) License, which permits unrestricted use, distribution, and reproduction in any medium, provided the original author and source are credited.

\section{REFERENCES}

1. Wu Z, McGoogan JM, 2020. Characteristics of and important lessons from the coronavirus disease 2019 (COVID-19) outbreak in China: summary of a report of 72314 cases from the Chinese center for disease control and prevention. J Am Med Assoc 323: 1239-1242.
2. Cascella M, Rajnik M, Cuomo A, Dulebohn SC, Di Napoli R, 2020. Features, Evaluation and Treatment Coronavirus (COVID-19). Napoli, Italy: StatPearls Publishing. Available at: http:// www.ncbi.nlm.nih.gov/pubmed/32150360. Accessed December 18, 2020.

3. Carter LJ et al., 2020. Assay techniques and test development for COVID-19 diagnosis. ACS Cent Sci 6: 591-605.

4. Li J, Zhang L, Liu B, Song D, 2020. Case report: viral shedding for 60 days in a woman with COVID-19. Am J Trop Med Hyg 102: 1210-1213.

5. Zapor M, 2020. Persistent detection and infectious potential of SARS-CoV-2 virus in clinical specimens from COVID-19 patients. Viruses 12: 1384

6. Khailany RA, Safdar M, Ozaslan M, 2020. Genomic characterization of a novel SARS-CoV-2. Gene Rep 19: 100682.

7. Li TZ et al., 2020. Duration of SARS-CoV-2 RNA shedding and factors associated with prolonged viral shedding in patients with COVID-19. J Med Virol 93: 506-512.

8. Baj A, Azzi L, Dalla Gasperina D, Genoni A, Tamborini A, Gambarini C, Carcano G, Grossi P, Sessa F, 2020. Pilot study: long-term shedding of SARS-CoV-2 in urine: a threat for dispersal in wastewater. Front Public Health 8: 569209.

9. Morone $\mathrm{G}$ et al., 2020. Incidence and persistence of viral shedding in COVID-19 post-acute patients with negativized pharyngeal swab: a systematic review. Front Med 7: 562.

10. Zheng $S$ et al., 2020. Viral load dynamics and disease severity in patients infected with SARS-CoV-2 in Zhejiang province, China, January-March 2020: retrospective cohort study. BMJ 369: $\mathrm{m} 1443$.

11. Fang Z, Zhang Y, Hang C, Ai J, Li S, Zhang W, 2020. Comparisons of viral shedding time of SARS-CoV-2 of different samples in ICU and non-ICU patients. $J$ Infect 81: 147-178.

12. Xu K et al., 2020. Factors associated with prolonged viral RNA shedding in patients with coronavirus disease 2019 (COVID-19). Clin Infect Dis 71: 799-806.

13. Yan D, Liu XY, Zhu YN, Huang L, Dan BT, Zhang GJ, Gao YH, 2020. Factors associated with prolonged viral shedding and impact of lopinavir/ritonavir treatment in hospitalised noncritically ill patients with SARS-CoV-2 infection. EurRespir J 56: 2000799.

14. Noh JY, Yoon JG, Seong H, Choi WS, Sohn JW, Cheong HJ, Kim WJ, Song JY, 2020. Asymptomatic infection and atypical manifestations of COVID-19: comparison of viral shedding duration. J Infect 81: 816-846.

15. Avanzato VA et al., 2020. Case study: prolonged infectious SARSCoV-2 shedding from an asymptomatic immunocompromised individual with cancer. Cell 183: 1901-1912.e9.

16. Nakajima $Y$, Ogai $A$, Furukawa $K$, Arai $R$, Anan $R$, Nakano $Y$, Kurihara Y, Shimizu H, Misaki T, Okabe N, 2020. Prolonged viral shedding of SARS-CoV-2 in an immunocompromised patient. $J$ Infect Chemother 27: 387-389.

17. Wise J, 2020. COVID-19: T cell response lasts for at least six months after infection, study shows. BMJ 371: $\mathrm{m} 4257$.

18. Huang I, Lim MA, Pranata R, 2020. Diabetes mellitus is associated with increased mortality and severity of disease in COVID-19 pneumonia - a systematic review, meta-analysis, and metaregression: diabetes and COVID-19. Diabetes Metab SyndrClin Res Rev 14: 395-403.

19. Bullard $J$ et al., 2020. Predicting infectious severe acute respiratory syndrome coronavirus 2 from diagnostic samples. Clin Infect Dis. doi: 10.1093/cid/ciaa638.

20. Singanayagam A, Patel M, Charlett A, Bernal JL, Saliba V, Ellis J, Ladhani S, Zambon M, Gopal R, 2020. Duration of infectiousness and correlation with RT-PCR cycle threshold values in cases of COVID-19, England, January to May 2020. Eurosurveillance 25: 1.

21. CDC, 2020. Interim Guidelines for Clinical Specimens for COVID-19. Available at: https://www.cdc.gov/coronavirus/ 2019-nCoV/lab/guidelines-clinical-specimens.html. Accessed December 19, 2020.

22. WHO, 2020. Criteria for releasing COVID-19 patients from isolation. Available at: https://www.who.int/publications/i/item/criteriafor-releasing-covid-19-patients-from-isolation. Accessed December 19, 2020. 